\title{
Catalytic Intermediate Pyrolysis of Napier Grass in a Fixed Bed Reactor with ZSM-5, HZSM-5 and Zinc-Exchanged Zeolite-A as the Catalyst
}

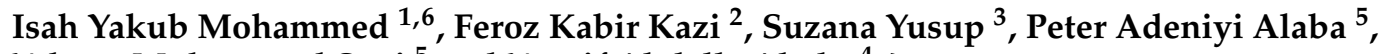 \\ Yahaya Muhammad Sani ${ }^{5}$ and Yousif Abdalla Abakr ${ }^{4, *}$ \\ 1 Department of Chemical and Environmental Engineering, the University of Nottingham Malaysia Campus, \\ Jalan Broga, Semenyih 43500, Darul Ehsan, Malaysia; kebx3iye@nottingham.edu.my \\ 2 Department of Engineering and Mathematics, Sheffield Hallam University, City Campus, Howard Street, \\ Sheffield S1 1WB, UK; f.kabir@shu.ac.uk \\ 3 Department of Chemical Engineering, Universiti Teknology Petronas (UTP) Bandar Seri Iskandar, \\ Tronoh 31750, Malaysia; drsuzana_yusuf@petronas.com.my \\ 4 Department of Mechanical, Manufacturing and Material Engineering, \\ the University of Nottingham Malaysia Campus, Jalan Broga, Semenyih 43500, Darul Ehsan, Malaysia \\ 5 Department of Chemical Engineering, University of Malaya, Kuala Lumpur 50603, Malaysia; \\ adeniyipee@live.com (P.A.A.); ymsani@siswa.um.edu.my (Y.M.S.) \\ 6 Crops for the Future (CFF), the University of Nottingham Malaysia Campus, Jalan Broga, Semenyih 43500, \\ Darul Ehsan, Malaysia \\ * Correspondence: yousif.abakr@nottingham.edu.my; Tel.: +60-132-321-232
}

Academic Editor: Tariq Al-Shemmeri

Received: 28 January 2016; Accepted: 21 March 2016; Published: 29 March 2016

\begin{abstract}
The environmental impact from the use of fossil fuel cum depletion of the known fossil oil reserves has led to increasing interest in liquid biofuels made from renewable biomass. This study presents the first experimental report on the catalytic pyrolysis of Napier grass, an underutilized biomass source, using ZSM-5, 0.3HZSM-5 and zinc exchanged zeolite-A catalyst. Pyrolysis was conducted in fixed bed reactor at $600{ }^{\circ} \mathrm{C}, 30^{\circ} \mathrm{C} / \mathrm{min}$ and $7 \mathrm{~L} / \mathrm{min}$ nitrogen flow rate. The effect of catalyst-biomass ratio was evaluated with respect to pyrolysis oil yield and composition. Increasing the catalyst loading from 0.5 to $1.0 \mathrm{wt} \%$ showed no significant decrease in the bio-oil yield, particularly, the organic phase and thereafter decreased at catalyst loadings of 2.0 and $3.0 \mathrm{wt} \%$. Standard analytical methods were used to establish the composition of the pyrolysis oil, which was made up of various aliphatic hydrocarbons, aromatics and other valuable chemicals and varied greatly with the surface acidity and pore characteristics of the individual catalysts. This study has demonstrated that pyrolysis oil with high fuel quality and value added chemicals can be produced from pyrolysis of Napier grass over acidic zeolite based catalysts.
\end{abstract}

Keywords: Napier grass; intermediate pyrolysis; catalytic deoxygenation; zeolite; bio-oil characterization

\section{Introduction}

Fossil fuels remain the main global energy supply source despite the environmental impacts cum sociopolitical concerns which are well documented in the literature [1-4]. The fear of energy insecurity in the near future, in addition to the need for reduction of greenhouse gases, has led to the development of energy from alternative renewable sources such as biomass, wind, solar and mini-hydro [5-8]. Among these renewable resources, biomass is the only renewable resource that has carbon in its building blocks which can be processed into liquid fuel. Lignocellulosic biomass (non-food materials) such as forest residues, agro-wastes, energy grasses, aquatic plants and algae, etc., have been 
seen as ideal raw materials in this direction as they avoid the initial public perception of food insecurity associated with first generation biofuels which were produced from food materials $[9,10]$. In addition, they have low levels of sulfur and nitrogen contents which make them relatively environmental friendly. Napier grass (Pennisetum purpureum) is one of the perennial grasses with potential high biomass yield, typically in the range of 25-35 oven dry tones per hectare annually, which correspond to 100 barrels of oil energy equivalent per hectare compared to other herbaceous plants [11,12]. Other advantages of Napier grass includes compatibility with conventional farming practices, and the fact that it outcompetes weeds, needs very little or no supplementary nutrients and therefore requires lower establishment cost. It can be harvested up to four times a year with a ratio of energy output to energy input of around 25:1 which makes it one of the highest potential energy crops for development of efficient and economic bioenergy systems [11,12].

Pyrolysis is currently one of the most promising thermochemical processes for converting biomass materials into products with high energy potential. Bio-oil, bio-char and non-condensable gas products are generally obtained in different proportions in any pyrolysis process. The distribution of pyrolysis products depends heavily on how the process parameters such as pyrolysis temperature, heating rate and vapor residence time are manipulated. Generally, there are different types of pyrolysis namely; slow, intermediate and fast pyrolysis. Slow pyrolysis is also referred to as carbonization. It is carried out at a temperature up to $400{ }^{\circ} \mathrm{C}$, for $60 \mathrm{~min}$ to days, with a typical product distribution of about $35 \%$ bio-char, $30 \%$ bio-oil, and 35\% non-condensable gas. Fast pyrolysis can produce up to $80 \%$ bio-oil, $12 \%$ bio-char, and $13 \%$ non-condensable gas at temperature around $500{ }^{\circ} \mathrm{C}$, with high heating rates, a short vapor residence time of about $1 \mathrm{~s}$, and rapid cooling of volatiles [13,14]. For intermediate pyrolysis, the operating conditions are $500-650{ }^{\circ} \mathrm{C}$ and the vapor residence time is approximately 10 to 30 s. About $40 \%-60 \%$ of the total product yield is usually bio-oil, $15 \%-25 \%$ bio-char and $20 \%-30 \%$ non-condensable gas. In addition, unlike fast pyrolysis, intermediate pyrolysis produce bio-oil with less reactive tar which can be used directly as a fuel in engines and boilers, and dry char suitable for both agricultural and energy applications [15-17].

The pyrolysis reactor represents the core unit of the entire pyrolysis process. It plays a very important role in the product distribution and accounts for about $10 \%-15 \%$ of the total capital cost [14]. A range of reactor designs are available, which include bubbling fluidized-bed reactors, circulating fluidized-bed reactors, fixed-bed reactors, auger reactors, ablative reactors, rotating cone reactors, etc. These reactors have been studied extensively to improve the efficiency of pyrolysis processes and the quality of bio-oil production. However, each reactor type has specific characteristics, pros and cons. In general, a good reactor design should exhibit high heating and heat transfer rates and should have an excellent temperature control capability [14].

Bio-oil from biomass pyrolysis is a complex mixture consisting predominantly oxygenated organic compounds, phenolics, light hydrocarbons and traces of nitrogen- and sulfur-containing compounds depending on the nature of the source biomass. The high level of oxygenated compounds in bio-oil is responsible for the oil's poor physicochemical characteristics such as low $\mathrm{pH}$, low chemical stability, lower energy content and therefore render it unsuitable for direct application as fuel or refinery ready feedstock for the production of quality fuels and other consumer products. In order to meet the target of having alternative fuel sources and reduce the challenges of fossil fuel on our environment, there is need to develop methods for reducing the oxygen content of bio-oil to a minimum level. Several deoxygenation methods are being developed in this direction, one of which is in situ deoxygenation. In situ upgrading involves the use of catalytic material to reduce oxygenated volatiles generated during pyrolysis prior to condensation through a series of chemical reactions such as decarboxylation, dehydration, and decarbonylation where oxygen is removed in the form of $\mathrm{CO}_{2}, \mathrm{H}_{2} \mathrm{O}$ and $\mathrm{CO}$, respectively. The process can be organized either by mixing the biomass with catalyst (in bed mixing) follow by pyrolysis, or by passing the pyrolysis vapor through a bed or beds of catalyst [18-23]. The most commonly used catalyst in this application are zeolite-based materials, particularly ZSM-5, due to their high acidity, shape selective pore structure, low affinity for coke formation owing to bulky molecules and high selectivity towards aromatic hydrocarbons [23-25]. Process parameters governing the yield and quality of bio-oil produced via the 
in situ upgrading include pyrolysis temperature, heating rate and catalyst- phthalenes decreased with an increasbiomass ratio (CBR) [26-29]. Liu et al. [29] studied the catalytic pyrolysis of duckweed with HZSM-5 revealed that the pyrolysis temperature and CBR affect the distribution of organic component in the product bio-oil. A high temperature was shown to favor the production of total monocyclic aromatic hydrocarbons such as benzene, toluene and xylene (BTX) while polyaromatic hydrocarbons $(\mathrm{PAH})$ such as indenes and nae in pyrolysis temperature. This trend was attributed to the exothermic nature of the oligomerization reactions. Similar observations have been reported by Kim et al. [30] during the in situ upgrading of pyrolysis vapor from unshiu citrus peel over HZSM-5. Studies by Ojha and Vinu [31] on resource recovery from polystyrene through fast catalytic pyrolysis using a zeolite-based catalyst also followed a similar trend. In terms of CBR, Liu et al. [29] stated that the increase in CBR promoted formation of BTX, while a downward trend was observed for PAH. This was contrary to the observation made by Ojha and Vinu [31]. They reported that an increase in CBR favored production of benzene among the monoaromatics while PAH yield increased with CBR. This difference in the observed trend could be linked to the characteristics of the respective catalysts used during those studies.

The impact of different zeolite-based catalysts on the production of aromatic hydrocarbons from pyrolysis of biomass materials such rice husk, Miscanthus, rice stalks, wood, corncobs, algae, etc., have been reported the literature. To the best of our knowledge, catalytic pyrolysis of Napier grass with zeolite catalysts has not been carried out. In addition, studies involving lower catalyst biomass ratios with potential practical applications are rarely carried out. Most literature studies employed the pyroprobe technique with high CBR and, in most cases the amount of catalyst used is equal or greater than the feedstock biomass. For large scale processes using in bed mixing technique, a large amount of catalyst material requirement may not be practicable technically and economically. The objective of this study was to investigate effect of the zeolites ZSM-5, and HZSM- 5 and zinc-exchanged zeolite-A catalyst loading on the yield and characteristics of Napier grass pyrolysis bio-oil.

\section{Experimental}

\subsection{Materials and Characterization}

Napier grass stem (NGS) with a particle size of around $2 \mathrm{~mm}$ was used in this study and the biomass has volatile matter, fixed carbon, ash content and higher heating value of $81.51 \mathrm{wt} \%$, $16.75 \mathrm{wt} \%, 1.75 \mathrm{wt} \%$ and $18.11 \mathrm{MJ} / \mathrm{kg}$ respectively. Ultimate analysis revealed that the biomass has $48.61 \mathrm{wt} \%$ carbon, $6.01 \mathrm{wt} \%$ hydrogen, $0.99 \mathrm{wt} \%$ nitrogen, $0.32 \mathrm{wt} \%$ sulfur and $44.07 \mathrm{wt} \%$ oxygen. Other details of its characteristics can be found in Mohammed et al. [12]. ZSM-5 and Zeolite A (zinc-exchanged: ZEOA) catalysts were purchased from Fisher Scientific Sdn. Bhd. (Selangor, Malaysia) and Sigma-Aldrich Sdn. Bhd. (Selangor, Malaysia) respectively. HZSM-5 was obtained from desilication of ZSM-5 with NaOH solution. ZSM-5 (30 g) was mixed with aqueous solution of $0.3 \mathrm{M} \mathrm{NaOH}(300 \mathrm{~mL})$ for $2 \mathrm{~h}$ at $70{ }^{\circ} \mathrm{C}$. The solid was filtered using vacuum filtration with the aid of a polyamide filter and thereafter oven dried at $100{ }^{\circ} \mathrm{C}$. The dried sample was transformed to hydronium form with $0.2 \mathrm{M} \mathrm{NH}_{4} \mathrm{NO}_{3}$ solution at $80^{\circ} \mathrm{C}$ for $24 \mathrm{~h}$, followed by overnight drying at $100{ }^{\circ} \mathrm{C}$ and calcination at $550{ }^{\circ} \mathrm{C}$ for $5 \mathrm{~h}$ and the final solid was designated as $0.3 \mathrm{HZSM}-5$. All the catalysts were characterized according to standard procedures. X-ray diffraction (XRD; PANalytical X'pertPro, DSKH Technology Sdn. Bhd.: Selangor, Malaysia; $\mathrm{CuK}_{\alpha}$ radiation, $\lambda=0.1541 \mathrm{~nm}$;) was used to examine the nature of the crystalline system at $2 \theta$ angles between $10^{\circ}$ and $60^{\circ}, 25 \mathrm{~mA}, 45 \mathrm{kV}$, step size of $0.025^{\circ}$, and $1.0 \mathrm{~s}$ scan rate. Scanning electron microscopy (SEM, FEI Quanta 400 FE-SEM, Hillsboro, OR, USA) was used to evaluate the surface and structural characteristics. Specific surface area and pore properties were determined using an ASAP 2020 physisorption analyzer (Micrometrics: Norcross, GA, USA). Acidity of the catalyst was determined via ammonia-temperature programmed desorption (TPD) using a ChemiSorb 2720 Pulse Chemisorption system (Micrometrics).

\subsection{Catalytic Pyrolysis and Pyrolysis Oil Characterization}

Our intermediate pyrolysis study was carried out in a fixed bed pyrolysis system as shown in Figure 1. The system consists of a fixed bed reactor made of stainless steel $(115 \mathrm{~cm}$ length, $6 \mathrm{~cm}$ inner 
diameter), a distribution plate with $1.0 \mathrm{~mm}$ hole diameter which sits at $25 \mathrm{~cm}$ from the bottom of the tube, two nitrogen preheating sections, a cyclone, a water chiller operating at $3{ }^{\circ} \mathrm{C}$ attached to a coil condenser, oil collector and gas scrubbers. $200 \mathrm{~g}$ of NGS (bone dry, $2.5 \mathrm{~mm}$ particle size) mixed with catalyst was placed on the distribution plate inside the reactor tube and pyrolysis was conducted under nitrogen atmosphere at $7 \mathrm{~L} / \mathrm{min}$. A pyrolysis temperature of $600{ }^{\circ} \mathrm{C}$ was used and the reactor was heated electrically at the rate of $30^{\circ} \mathrm{C} / \mathrm{min}$. The reaction temperature was monitored with a K-type thermocouple connected to a computer through a data logger. The reaction time was kept at $15 \mathrm{~min}$ ( $\pm 2 \mathrm{~min}$ ) or until no significant amount of non-condensable gas was observed after the reaction temperature reaches $600^{\circ} \mathrm{C}$. Effect of catalyst loading was first evaluated with $0.5,1,2$ and $3 \mathrm{wt} \%$ ZSM-5. The optimum oil yield conditions were then used with 0.3HZSM-5 and ZEOA catalyst. Non-catalytic pyrolysis product yield was used as a control. Characterization of bio-oil collected was carried out according to standard procedures. A WalkLAB microcomputer $\mathrm{pH}$ meter T19000 (Trans Instruments, Singapore) was used to determine the $\mathrm{pH}$. Water content in the bio-oil was determined using a Karl Fischer V20 volumetric titrator (Mettler Toledo: Columbus, OH, USA) [32,33]. Higher heating value was determined using an oxygen bomb calorimeter (Parr 6100, Parr Instruments: Molin, IL, USA) [33,34]. Density and viscosity were determined using an Anton Paar density meter (DMA $4500 \mathrm{M}$, Ashland, VA, USA) and Brookfield (Hamilton, NJ, USA) DV-E viscometer, respectively. Bio-oil elemental compositions were determined using a Perkin Elmer 2400 Series II CHNS/O analyzer (Perkin Elmer Sdn Bhd.: Selangor, Malaysia). Chemical functional groups in the bio-oil were determined with FTIR (Spectrum RXI, PerkinElmer: Selangor, Malaysia) using a pair of circular demountable potassium bromide $(\mathrm{KBr})$ cell windows ( $25 \mathrm{~mm}$ diameter and $4 \mathrm{~mm}$ thickness). Spectra were recorded with the Spectrum V5.3.1 software within the wavenumber range of $400-4000 \mathrm{~cm}^{-1}$ at 32 scans and a resolution of $4 \mathrm{~cm}^{-1}$. Details of the chemical composition of the bio-oil was determined using a gas chromatograph-mass spectrometer (GC-MS) system (PerkinElmer Clarus ${ }^{\circledR}$ SQ 8: Akron, OH, USA) with a quadruple detector and PerkinElmer-Elite ${ }^{\mathrm{TM}}-5 \mathrm{~ms}$ column $(30 \mathrm{~m} \times 0.25 \mathrm{~mm} \times 0.25 \mu \mathrm{m})($ Akron, $\mathrm{OH}, \mathrm{USA}$ ). The oven was programmed at an initial temperature of $40{ }^{\circ} \mathrm{C}$, ramp at $5^{\circ} \mathrm{C} / \mathrm{min}$ to $280^{\circ} \mathrm{C}$ and held there for $20 \mathrm{~min}$. The injection temperature, volume, and split ratio were $250^{\circ} \mathrm{C}, 1 \mu \mathrm{L}$, and 50:1 respectively. Helium was used as carrier gas at a flow rate of $1 \mathrm{~mL} / \mathrm{min}$. The bio-oil samples in chloroform $(10 \%, w / v)$ were prepared and used for the analysis. MS ion source at $250{ }^{\circ} \mathrm{C}$ with $70 \mathrm{eV}$ ionization energy was used. Peaks of the chromatogram were identified by comparing with standard spectra of compounds in the National Institute of Standards and Technology (NIST: Gaithersburg, MD, USA) library.

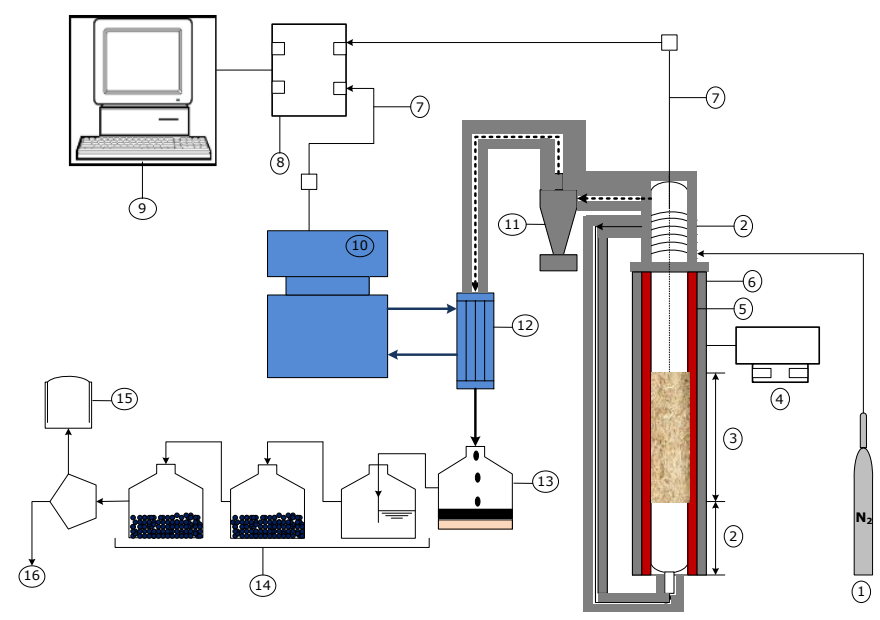

Figure 1. Experimental set-up. (1) Nitrogen cylinder; (2) nitrogen preheating sections; (3) pyrolysis section; (4) furnace controller; (5) heater; (6) insulator; (7) thermocouples; (8) data logger; (9) computer; (10) water chiller; (11) cyclone; (12) condenser; (13) bio-oil collector; (14) gas scrubber; (15) gas sampling bag; (16) gas venting. 
Samples of the non-condensable pyrolysis product were collected in a gas SKC polypropylene fitted gas sampling bag for each experiment and its composition analyzed using a gas chromatography PerkinElmer Clarus 500 (Akron, OH, USA) equipped with a stainless steel column (Porapak R 80/100) and thermal conductivity detector (TCD). Helium was used as a carrier gas and the GC was programed at $60^{\circ} \mathrm{C}, 80^{\circ} \mathrm{C}$ and $200{ }^{\circ} \mathrm{C}$ for oven, injector and TCD temperature, respectively.

\section{Results and Discussion}

\subsection{Catalyst Characteristics}

XRD patterns of the zeolites are presented in Figure 2. The parent ZSM- 5 exhibited main peaks at around $2 \theta$ between $20^{\circ}$ and $25^{\circ}$, which are typical characteristic peaks for ZSM- 5 . The decrease in the intensity of the peaks observed in the 0.3HZSM- 5 indicates a loss of crystallinity as a result of desilication [35] which may also be related to the formation of mesoporous structures in the material [36-41]. The peaks observed in ZEOA at around $10.1^{\circ}, 16.1^{\circ}, 21.4^{\circ}, 27.1^{\circ}, 29.9^{\circ}$ and $35^{\circ}$ are distinctive characteristics peaks of zeolite A [42-44]. SEM images showing the morphology of the zeolites are presented in Figure 3.

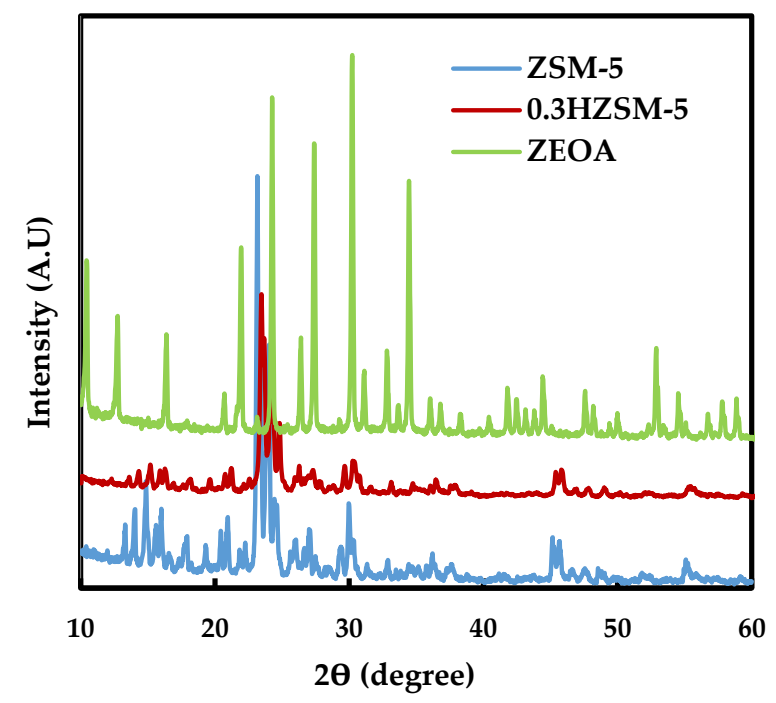

Figure 2. Diffractograms of ZSM-5, 0.3HZSM-5 and ZEOA.
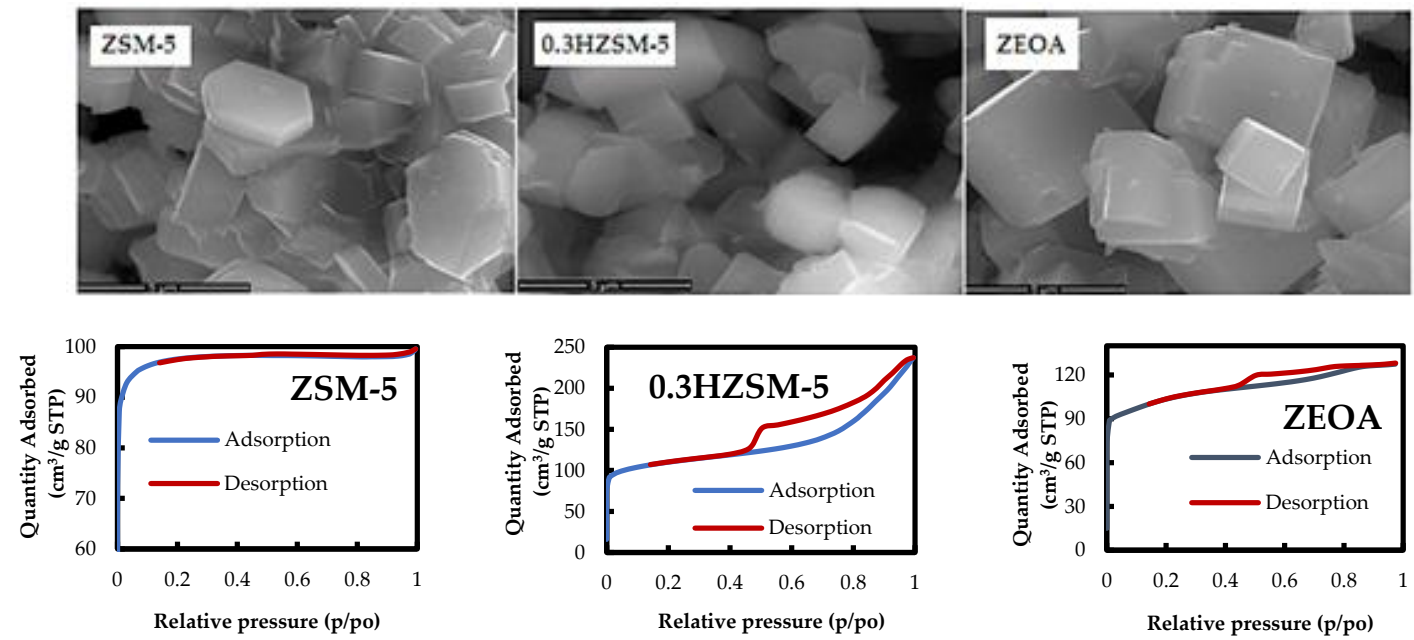

Figure 3. Cont. 


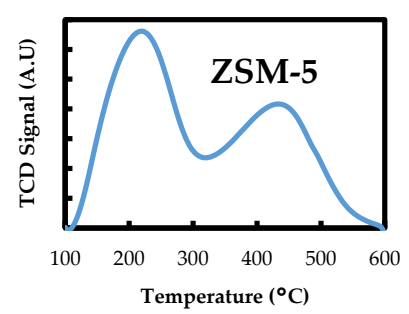

(a)

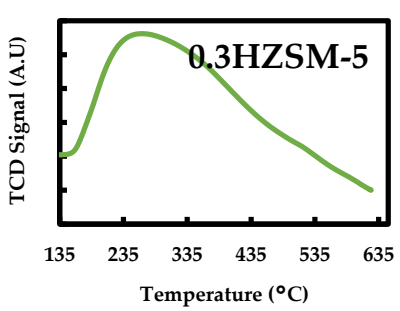

(b)

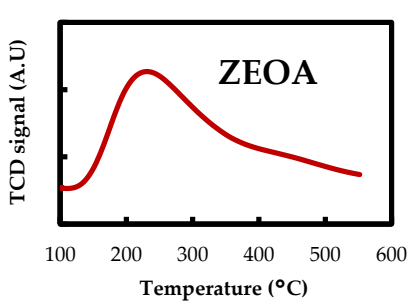

(c)

Figure 3. Characteristics (SEM, BET and TPD) of (a) ZSM-5, (b) 0.3HZSM-5 and (c) ZEOA.

The SEM micrographs indicated that ZSM-5 is highly crystalline, with hexagonal prismatic morphology and different particle size of less than $500 \mathrm{~nm}$. 0.3HZSM-5 showed morphological characteristic similar to the parent ZSM-5 indicting that desilication does not affect the morphological integrity of the catalyst. ZEOA exhibited an extremely crystalline system with cubical structure having smooth ages, which is a typical characteristic of zeolite A.

From the result of the physisorption analysis (Figure 3), ZSM-5 displayed a type I isotherm according to the IUPAC classification. The isotherm showed a very strong adsorption in the initial region and a plateau at high relative pressure $(>0.9)$. This pattern indicates that ZSM- 5 is a microporous material [44]. 0.3HZSM-5 displayed a combination of type I and IV isotherms with a low slope region at the middle which indicates the presence of few multilayers and a hysteresis loop at relative pressures above 0.4 that could be attributed to capillary condensation in a mesoporous material $[45,46]$. This observation is in good agreement with the XRD results. ZEOA also displayed an isotherm similar to that of $0.3 \mathrm{HZSM}-5$ with a visible but less pronounced hysteresis loop. This indicates that ZEOA is made up of some mesoporous structures. Other characteristics and physisorption analysis are summarized in Table 1. Comparing ZSM-5 and 0.3HZSM-5, Brunauer Emmet Teller (BET) specific surface area $\left(\mathrm{S}_{\mathrm{BET}}\right)$ and $\mathrm{S}_{\text {micro }}$ decreased after desilication. A decrease in the micropore volume of the 0.3HZSM- 5 was also observed after desilication compared to the parent ZSM-5, which suggest that the conversion of the microporous structure during the desilication contributed to the resultant mesoporosity in the 0.3HZSM-5 [45]. The results of $\mathrm{NH}_{3}$-TPD analysis (Figure 3) showed two peaks at temperatures around 219 and $435^{\circ} \mathrm{C}$ for ZSM-5, while single peaks around $258^{\circ} \mathrm{C}$ and $229^{\circ} \mathrm{C}$ was observed for $0.3 \mathrm{HZSM}-5$ and ZEOA, respectively. The high temperature peak represents the desorption of $\mathrm{NH}_{3}$ from strong acid sites while those at temperatures between 219 and $258{ }^{\circ} \mathrm{C}$ are attributed to desorption of $\mathrm{NH}_{3}$ from weak acid sites [31,35,36,46]. Disappearance of the strong acid sites in the 0.3 HZSM- 5 is attributed to desilication. Similar observations have been reported in the literature $[45,46]$. The area under each peak was evaluated and the corresponding total surface acidity was $3.8085 \mathrm{mmol} / \mathrm{g}$ for ZSM-5, while 2.9635 and $1.21 \mathrm{mmol} / \mathrm{g}$ were recorded for $0.3 \mathrm{HZSM}-5$ and ZEOA, respectively.

Table 1. Textural characteristics of ZSM-5, 0.3HZSM-5 and ZEOA.

\begin{tabular}{cccc}
\hline Property & ZSM-5 & $\mathbf{0 . 3 H Z S M - 5}$ & ZEOA \\
\hline $\mathrm{Si} / \mathrm{Al} \mathrm{ratio}$ & 20.7600 & 12.5100 & 1.0000 \\
$\mathrm{~S}_{\mathrm{BET}}\left(\mathrm{m}^{2} / \mathrm{g}\right)$ & 385.2000 & 374.8800 & 367.0000 \\
$\mathrm{~S}_{\text {micro }}\left(\mathrm{m}^{2} / \mathrm{g}\right)$ & 356.5400 & 240.2300 & 315.7200 \\
$\mathrm{~S}_{\text {meso }}\left(\mathrm{m}^{2} / \mathrm{g}\right)$ & 28.6600 & 134.6500 & 93.3100 \\
$\mathrm{~V}_{\text {micro }}\left(\mathrm{m}^{3} / \mathrm{g}\right)$ & 0.1383 & 0.1114 & 0.1240 \\
Total acidity $(\mathrm{mmol} / \mathrm{g})$ & 3.8085 & 2.9635 & 1.2100 \\
\hline
\end{tabular}




\subsection{Pyrolysis Product Distribution}

The effect of ZMS-5 loading with respect to pyrolysis product distribution compared to the non-catalytic pyrolysis (NCP) is shown in Figure 4a. Bio-oil here constituted the total liquid product (organic: OR and aqueous: AQ phase); bio-char is the total solids, including coke. The bio-oil recorded from the NCP (raw) was $41.91 \mathrm{wt} \%(12.34 \mathrm{wt} \% \mathrm{OR} ; 29.57 \mathrm{wt} \% \mathrm{AQ})$ with corresponding bio-char and non-condensable gas values of 29.24 and $28.85 \mathrm{wt} \%$. For the catalytic process, the bio-oil yield decreased to $40.07 \mathrm{wt} \%$ (11.25 wt \% OR; $28.82 \mathrm{wt} \%$ AQ) at a catalyst loading of $0.5 \mathrm{wt} \%$. Increasing the catalyst loading from 0.5 to $1.0 \mathrm{wt} \%$ showed no significant decrease in the bio-oil yield, particularly for the organic phase, and $38.88 \mathrm{wt} \%$ oil (11.15 wt \% OR; $27.74 \mathrm{wt} \% \mathrm{AQ})$ was recorded. Thereafter, the oil yield decreased to $33.29 \mathrm{wt} \%(9.43 \mathrm{wt} \%$ OR; $23.86 \mathrm{wt} \% \mathrm{AQ})$ and $30.35 \mathrm{wt} \%$ (7.48 wt \% OR; 22.87 $\mathrm{wt} \% \mathrm{AQ}$ ) at catalyst loadings of 2.0 and $3.0 \mathrm{wt} \%$, respectively. Comparing with the existing literature, most researchers employed high catalyst to biomass ratios which generally lead to less liquid yield and more gas production [21,47-49]. Studies involving catalyst loadings similar to the ones used in this study, particularly between 0.5 and $1.0 \mathrm{wt} \%$, are seldom carried out. Research conducted by Park et al. [50] on catalytic pyrolysis of Miscanthus with ZSM-5 using a catalyst to biomass ratio of 0.1 and a reaction temperature of $450^{\circ} \mathrm{C}$ in a fixed bed reactor resulted in a high yield of organic phase (21.5 wt \%). Similarly, the work of Elordi et al. [51] on catalytic pyrolysis of polyethylene with ZSM-5 using a catalyst/biomass ratio of 0.03 at $500{ }^{\circ} \mathrm{C}$ in a spouted bed reactor generated about $25 \mathrm{wt} \%$ organic product. Furthermore, under low ZSM-5 loading conditions ( 0.5 and $1.0 \mathrm{wt} \%$ ), a high yield of organic phase was recorded compared to 2.0 and $3.0 \mathrm{wt} \%$ ZSM- 5 loading. This could be attributed to the generation of less reactive pyrolysis vapor via simultaneous dehydration, decarboxylation, and decarbonylation reactions. The non-condensable gas yield under this catalytic condition was higher compared to the non-catalytic pyrolysis and also increased with catalyst loading, suggesting a high degree of decarboxylation and decarbonylation reactions. The bio-char yield during the catalytic process with ZSM-5 was $29.24,29.79,30.12$ and $30.22 \mathrm{wt} \%$ at $0.5,1.0,2.0$ and $3.0 \mathrm{wt}$ catalyst. These values are similar to that of bio-char yield obtained with the NCP $(29.24 \mathrm{wt} \%)$. The small increment, particularly at ZSM-5 loadings from 1.0 to $3.0 \mathrm{wt} \%$, could be attributed to coke deposits. This observation is in good agreement with the literature [48,52]. Also, comparing the impact of ZSM-5 with $0.3 \mathrm{HZSM}-5$ and ZEOA, the bio-oil yield obeyed the following order: ZEOA > ZSM-5 > 0.3HZSM-5. The bio-oil from ZEOA constitutes a large percentage of the AQ phase (34.89 wt \%) which is largely water resulting from deoxygenation reactions. The low yield of the OR phase with the ZEOA catalyst is an indication of secondary reactions in which oxygen is removed in form of water as the main reaction product. The non-condensable gas yield recorded with ZEOA was lower than that $0.3 \mathrm{HZSM}-5$ and ZSM-5, while the bio-char yield was comparable to those obtained with the other catalysts. The overall impact of ZEOA on the product distribution could be attributed to a combined effect of the zinc cation in the catalyst, its acidity and porosity [53]. Therefore the non-condensable fraction may also consist of substantial amounts of $\mathrm{CO}_{2}$. A similar trend of pyrolysis product distribution related to zinc cation in the catalyst and low SAR has been reported in the literature [54,55].

Bio-oil yield from 0.3HZSM-5 was $31.14 \mathrm{wt} \%$ (10.03 wt \% OR and $25.11 \mathrm{wt} \%$ AQ phase) compared to $40.07 \mathrm{wt} \%$ (11.25 wt \% OR; $28.82 \mathrm{wt} \%$ AQ) ZSM-5 oil yield. The reduction in the organic phase recorded with $0.3 \mathrm{HZSM}-5$ may be attributed to the improved pore structures which perhaps led to cracking of large organic molecules. This can also be backed up by the higher non-condensable gas amount of $34.29 \mathrm{wt} \%$ recorded, compared to $30.69 \mathrm{wt} \%$ from ZSM-5. This shows that improvement in the pore structure reduces the diffusion resistance of large oxygenates which will otherwise be deposited on the catalyst surface as coke which is generally encountered with microporous materials [45]. 

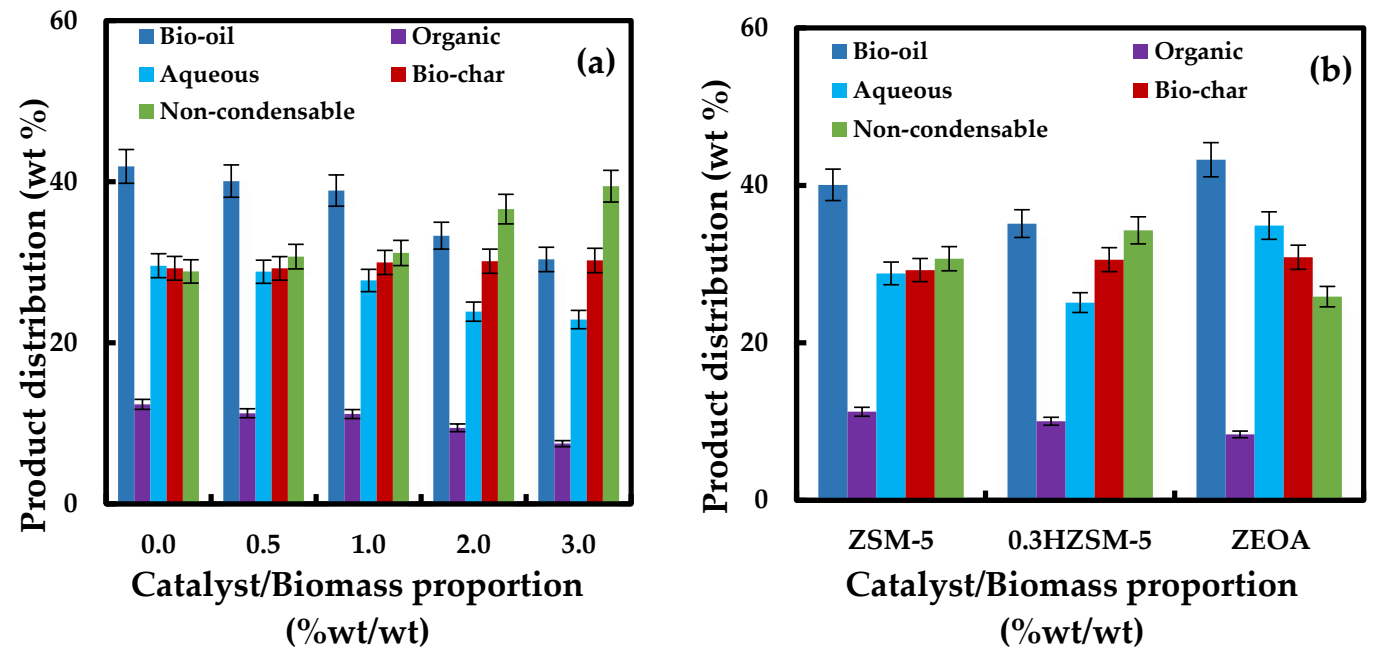

Figure 4. Pyrolysis products distribution (a) Effect of ZSM-5 loading; (b) impact of 0.3HZSM-5 and ZEOA at $0.5 \mathrm{wt} \%$ loading compared to ZSM-5.

\subsection{Physicochemical Properties of Organic Phase Product}

The properties of the organic phase bio-oil collected are summarized in Table 2. The $\mathrm{pH}$ values of the oil from all the ZSM-5 loadings and HZSM-5 were between 2.79 and 2.98, while the oil from ZEOA had a $\mathrm{pH}$ value of 3.57. Comparing the oil from the catalytic process with that from the non-catalytic process ( $\mathrm{pH}$ of 2.71), some level of improvement in the acidity of the oil was recorded which can be attributed to a reduction of phenolic compounds through decarbonylation reactions. The water content of the catalytically produced oil was between 9.1 and $10.8 \mathrm{wt} \%$ compared to $8.64 \mathrm{wt} \%$ recorded for the oil from the non-catalytic process. Decreases in the density and viscosity of the oil from all the catalysts was observed compared to the oil from the non-catalytic process. This indicates that the catalysts increased the production of small molecules, which contributed to a lower viscosity [39]. A high content of reaction generally accounts for the lower density and viscosity of bio-oils [56-58]. From the ultimate analysis result (Table 2), the impact of catalyst on the elemental composition of the bio-oil was more pronounced on its carbon and oxygen contents, which also directly affected the heating value.

Table 2. Physicochemical properties of the organic phase bio-oils.

\begin{tabular}{|c|c|c|c|c|c|c|c|}
\hline \multicolumn{2}{|l|}{ Bio-Oil } & \multicolumn{4}{|c|}{ ZSM-5 (wt \%) } & \multirow{2}{*}{$\frac{\mathbf{0 . 3 H Z S M - 5}}{0.5}$} & \multirow{2}{*}{$\frac{\text { ZEOA }}{0.5}$} \\
\hline Property & Raw & 0.5 & 1.0 & 2.0 & 3.0 & & \\
\hline \multicolumn{8}{|c|}{ Proximate analysis } \\
\hline $\mathrm{pH}$ & $2.71 \pm 0.01$ & $2.83 \pm 0.01$ & $2.93 \pm 0.01$ & $2.98 \pm 0.01$ & $2.79 \pm 0.01$ & $2.91 \pm 0.01$ & $3.57 \pm 0.01$ \\
\hline $\mathrm{H}_{2} \mathrm{O}(\mathrm{wt} \%)$ & $8.64 \pm 0.23$ & $9.50 \pm 0.25$ & $9.60 \pm 0.23$ & $10.00 \pm 0.26$ & $10.20 \pm 0.23$ & $9.60 \pm 0.24$ & $10.80 \pm 0.26$ \\
\hline Viscosity $(c \mathrm{P}) *$ & $2.82 \pm 0.14$ & $2.80 \pm 0.13$ & $2.80 \pm 0.13$ & $2.78 \pm 0.13$ & $2.74 \pm 0.14$ & $2.81 \pm 0.15$ & $2.70 \pm 0.13$ \\
\hline Density $\left(\mathrm{g} / \mathrm{cm}^{3}\right) *$ & $1.082 \pm 0.0$ & $1.059 \pm 0.0$ & $1.056 \pm 0.0$ & $1.040 \pm 0.0$ & $1.002 \pm 0.0$ & $1.051 \pm 0.0$ & $0.998 \pm 0.0$ \\
\hline \multicolumn{8}{|c|}{ Ultimate analysis (wt \% w.b) } \\
\hline Carbon $(\mathrm{C})$ & $49.97 \pm 1.50$ & $59.92 \pm 1.79$ & $61.65 \pm 1.66$ & $63.84 \pm 1.84$ & $64.69 \pm 1.82$ & $65.61 \pm 1.80$ & $63.98 \pm 1.79$ \\
\hline Hydrogen $(\mathrm{H})$ & $6.79 \pm 0.07$ & $6.82 \pm 0.07$ & $6.63 \pm 0.06$ & $7.47 \pm 0.07$ & $6.6 \pm 0.06$ & $6.46 \pm 0.07$ & $6.34 \pm 0.07$ \\
\hline Nitrogen $(\mathrm{N})$ & $1.35 \pm 0.03$ & $0.95 \pm 0.02$ & $0.85 \pm 0.02$ & $0.53 \pm 0.02$ & $0.97 \pm 0.02$ & $0.89 \pm 0.02$ & $0.57 \pm 0.02$ \\
\hline Sulfur (S) & $0.6 \pm 0.01$ & $0.51 \pm 0.01$ & $0.46 \pm 0.01$ & $0.43 \pm 0.01$ & $0.4 \pm 0.01$ & $0.44 \pm 0.01$ & $0.41 \pm 0.01$ \\
\hline Oxygen $(\mathrm{O})^{* *}$ & $41.29 \pm 1.07$ & $31.8 \pm 0.86$ & $30.41 \pm 0.88$ & $27.73 \pm 0.83$ & $27.34 \pm 0.79$ & $26.6 \pm 0.88$ & $27.34 \pm 0.88$ \\
\hline $\mathrm{HHV}(\mathrm{MJ} / \mathrm{kg})$ & $26.23 \pm 0.10$ & $28.29 \pm 0.10$ & $27.87 \pm 0.10$ & $27.57 \pm 0.10$ & $28.23 \pm 0.10$ & $28.24 \pm 0.10$ & $27.29 \pm 0.10$ \\
\hline \multicolumn{8}{|c|}{ Ultimate analysis (wt \% d.b) } \\
\hline $\mathrm{C}$ & 54.7 & 66.21 & 68.2 & 70.93 & 71.17 & 72.58 & 71.73 \\
\hline $\mathrm{H}$ & 6.38 & 6.37 & 6.15 & 7.07 & 6.15 & 5.97 & 5.76 \\
\hline $\mathrm{O}$ & 36.79 & 25.81 & 24.2 & 20.93 & 21.18 & 19.99 & 21.41 \\
\hline HHV (MJ/kg) & 28.92 & 31.5 & 31.07 & 30.88 & 31.29 & 31.48 & 30.87 \\
\hline $\operatorname{DOD}(\%)$ & 0.00 & 29.85 & 34.22 & 43.11 & 42.43 & 45.66 & 41.80 \\
\hline
\end{tabular}

${ }^{*}$ Measured at $20^{\circ} \mathrm{C} ;{ }^{* *}$ by difference $[\mathrm{O}=100-(\mathrm{C}+\mathrm{H}+\mathrm{N}+\mathrm{S})]$. 
All the catalytically produced oils have higher carbon and lower oxygen contents, which resulted in higher energy content compared to the oil produced without catalyst. Increased ZSM-5 loading and the improved pore characteristics of 0.3HZSM- 5 and ZEOA produced oil with higher carbon and lower oxygen content. The dry basis elemental composition and relative degree of deoxygenation (DOD) was computed according to Equations (1), (2), (3) [59] and (4), respectively:

$$
\begin{gathered}
\mathrm{C}_{\text {dry }}=\frac{\mathrm{C}_{\text {wet }}}{\left[1-\left(\frac{\mathrm{H}_{2} \mathrm{O}}{100}\right)\right]} \\
\mathrm{H}_{\text {dry }}=\frac{\left[\mathrm{H}_{\text {wet }}\right]-\left[\mathrm{H}_{2} \mathrm{O} \times\left(\frac{(2 \times \mathrm{MWH})}{(2 \mathrm{MWH}+\mathrm{MWO})}\right)\right]}{\left[1-\left(\frac{\mathrm{H}_{2} \mathrm{O}}{100}\right)\right]} \\
\mathrm{O}_{\text {dry }}=\frac{\left[\mathrm{O}_{\mathrm{wet}}\right]-\left[\mathrm{H}_{2} \mathrm{O} \times\left(\frac{(\mathrm{MWO})}{(2 \mathrm{MWH}+\mathrm{MWO})}\right)\right]}{\left[1-\left(\frac{\mathrm{H}_{2} \mathrm{O}}{100}\right)\right]} \\
\operatorname{DOD}(\%)=\left[1-\left(\frac{\mathrm{O}_{\text {cat }}}{\mathrm{O}_{\text {Ncat }}}\right)\right] \times 100
\end{gathered}
$$

where $\mathrm{C}, \mathrm{H}$ and $\mathrm{O}$ is carbon, hydrogen and oxygen content in wt $\% ; \mathrm{H}_{2} \mathrm{O}$ is the water content of the oil (wt \%); $\mathrm{MWH}$ and $\mathrm{MWO}$ is atomic weight of hydrogen and oxygen; $\mathrm{O}_{\text {cat }}$ and $\mathrm{O}_{\mathrm{Ncat}}$ are the oxygen contents (wt \%) of oil from the catalytic and non-catalytic process. The results show that better quality bio-oil can be produced with high catalyst loading, but at the expense of quantity.

\subsection{Thermogravimetric Analysis of the Organic Phase Bio-Oil}

The use of thermogravimetric method for analyzing bio-oil provides insights into the type or groups of organic compound present in the oil based on thermal characteristics such as evaporation and reactivity with respect to temperature. The bio-oil collected in this study was subjected to a thermogravimetric study (TGA) using a Perkin Elmer simultaneous thermal analyzer thermogravimetric analyzer (STA 6000) in a nitrogen atmosphere, flow rate $20 \mathrm{~mL} / \mathrm{min}$ at temperatures between ambient to $500{ }^{\circ} \mathrm{C}$ and a heating rate of $10^{\circ} \mathrm{C} / \mathrm{min}$. Approximately $10 \mathrm{mg}$ of sample was used in each run and the results are shown in Figure 5.
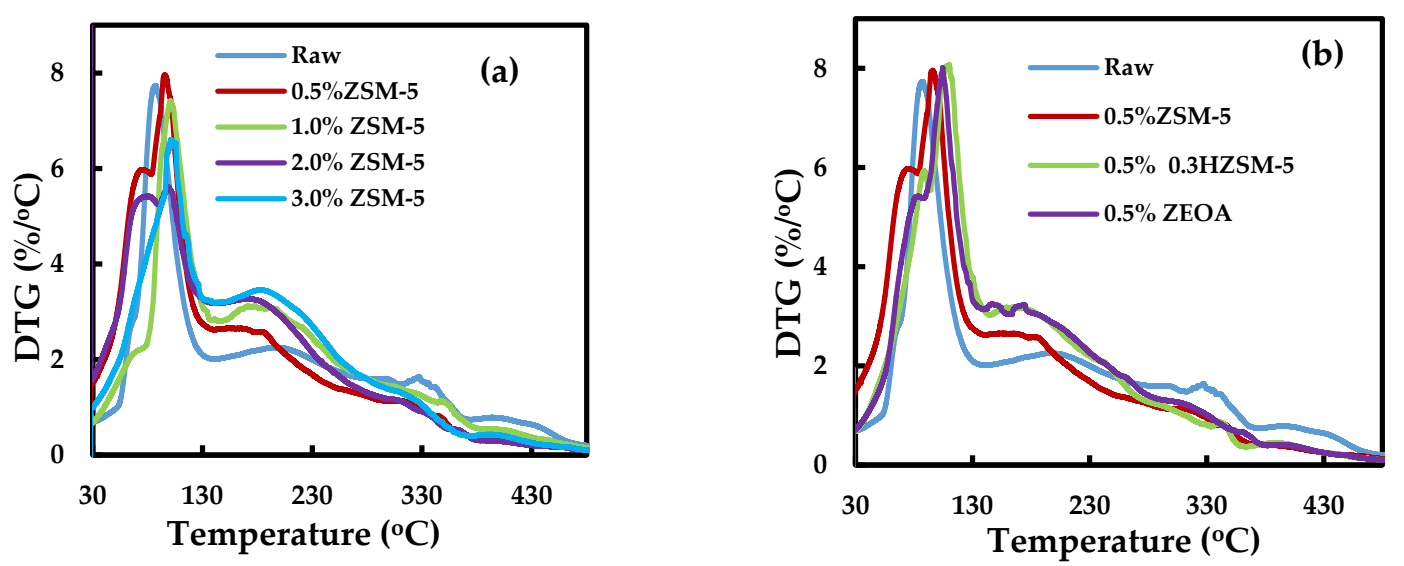

Figure 5. Cont. 

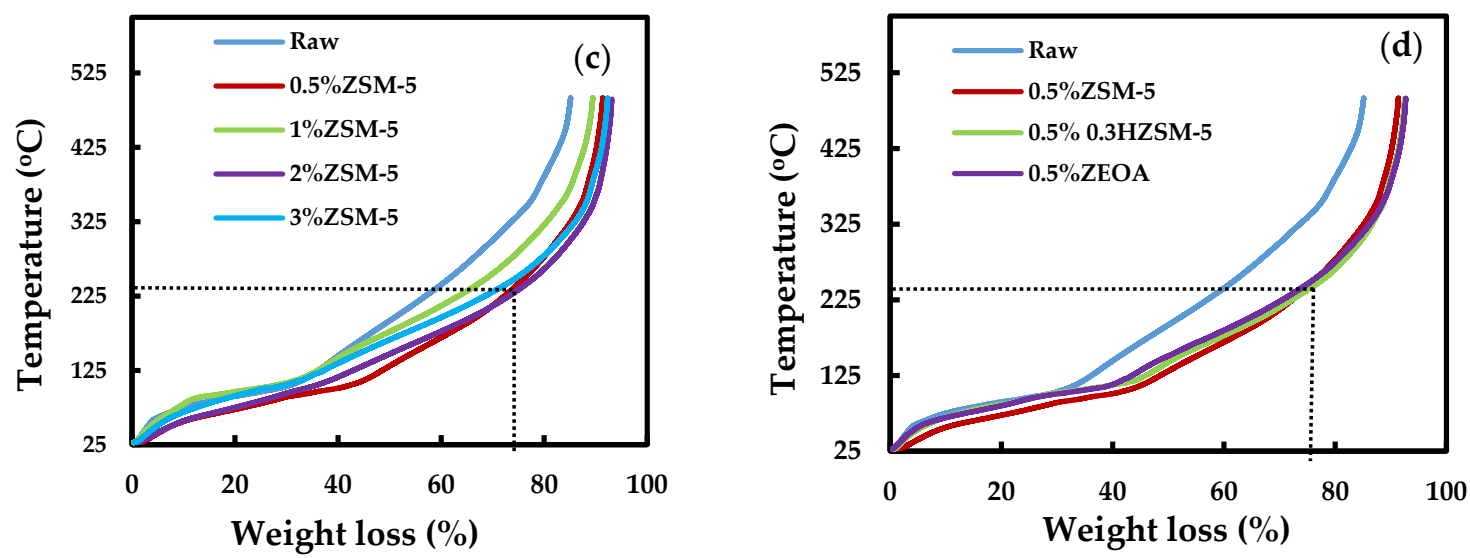

Figure 5. DTG $(\mathbf{a}, \mathbf{b})$ and TG $(\mathbf{c}, \mathbf{d})$ curves of organic bio-oil produced with and without catalysts.

The bio-oil fractions have been grouped into light, medium and heavy fractions. The light fractions consist of volatile organic compounds such as acids, alcohols and other compounds with boiling points close to the boiling point of water. Phenolics, furans and simple sugars such as levoglucosan constitute the medium fractions, while oligomers derived from hemicellulose, cellulose and lignin made up the heavy fractions [60]. The study by Garcia-Perez et al. [61] categorized bio-oil fractions into macro-groups such as volatile non-polar and polar compounds, monolignols, polar compounds with moderate volatility, sugars, extractive derived compounds, and heavy polar and non-polar compounds. From the results obtained in this present study (Figure 5), the DTG curves exhibited four (4) characteristic peaks at temperatures between of $45-100{ }^{\circ} \mathrm{C}, 140-230{ }^{\circ} \mathrm{C}, 275-365{ }^{\circ} \mathrm{C}$ and $370-440{ }^{\circ} \mathrm{C}$. The peaks between 45 and $100{ }^{\circ} \mathrm{C}$ could be due to evaporation of the light fractions. ZSM-5 loading led to formation of a shoulder around $70-80{ }^{\circ} \mathrm{C}$ (Figure 5a). This represents a generation of more volatile organic compounds during pyrolysis with catalyst loading which may be ascribed to alkanes, alcohols and alkenols. Alkenols are generally intermediate products of the decarboxylation of acetic acid at elevated temperature [62]. The peak around $83{ }^{\circ} \mathrm{C}$ for the oil from the non-catalytic process shifted to $93,96,98$ and $99^{\circ} \mathrm{C}$ for ZSM-5 loadings of $0.5,1.0,2.0$ and $3.0 \mathrm{wt} \%$, respectively. These may be attributed to vaporization of volatile non-polar compounds such as aromatic hydrocarbons [61]. The peaks observed around $140-230{ }^{\circ} \mathrm{C}$ may be related to vaporization of phenolics and hydroxybenzenes. The peak in this temperature range was more pronounced with increased ZSM-5 loading which can be attributed to the presence of more hydroxybenzenes in the bio-oil produced with catalyst. Peaks observed at $275-365{ }^{\circ} \mathrm{C}$ and $370-440{ }^{\circ} \mathrm{C}$ may be attributed to extractive-derived compounds such as oligomers from the structural carbohydrates $[60,62]$. The peaks level off with ZSM-5 loading which are indications of a reduction of oligomers by ZSM-5 during the pyrolysis. A similar trend was also observed with 0.3HZSM- 5 and ZEOA as presented in Figure $5 \mathrm{~b}$. The TG curves (Figure $5 c, d$ ) give the percentage of weight lost with respect to the temperature. It provides information about the volatile fraction of bio-oils. At $250^{\circ} \mathrm{C}$, the total weight loss of the raw bio-oil was about $60 \mathrm{wt} \%$, which corresponds to the amount of volatiles present in it. This fraction increased to about $72 \mathrm{wt} \%$ in the oil produced by the catalytic process. The weight loss observed above $250{ }^{\circ} \mathrm{C}$ could be attributed to the thermal degradation of oligomers. Furthermore, this result suggests that only $60 \mathrm{wt} \%$ and $72 \mathrm{wt} \%$ of the bio-oil from the non-catalytic and catalytic pyrolysis can be analyzed with GC-MS. Hence, the injector temperature of $250{ }^{\circ} \mathrm{C}$ chosen in Section 2.2 above for the GC-MS analysis is adequate.

\subsection{Functional Group Analysis of Bio-Oils}

The FTIR spectra of chemical compounds in the bio-oil samples are shown in Figure 6a,b. The broad peak around $3420 \mathrm{~cm}^{-1}$ in all bio-oil samples is an indication that samples contain chemical 
compounds with hydroxyl groups $(-\mathrm{OH})$ such as water, alcohols and phenols $[63,64]$. The peak became wider (Figure 6a) in the oil produced by the catalytic process with increasing ZSM-5 loading, which can be ascribed to the increased moisture level in the oil samples. The peak at a frequency around $2920 \mathrm{~cm}^{-1}$ is due to the $\mathrm{C}-\mathrm{H}$ stretching vibrations of methyl and methylene groups which are common to all the bio-oil samples, indicating the presence of saturated hydrocarbons while the broad peak at frequency around $2091 \mathrm{~cm}^{-1}$ is attributed to $C \equiv C$ functional groups which denote the presence of alkynes [63,64]. Sharp vibrations observed around $1707 \mathrm{~cm}^{-1}$ in the oil produced by the non-catalytic process are ascribed to $\mathrm{C}=\mathrm{O}$ which signifies the presence of aldehydes, ketones or carboxylic acids. This peak diminished in all the oils from the ZSM-5 process with increasing catalyst loading. Also, the stretching vibration observed in the former around $1625 \mathrm{~cm}^{-1}$ due to the $\mathrm{C}=\mathrm{O}$ functional group of ketones disappeared completely in the latter. These observations confirm the extent of deoxygenation in the oil by the ZSM- 5 catalyst. The vibrations around 1462 and $1384 \mathrm{~cm}^{-1}$ common to all the samples are ascribed $\mathrm{C}=\mathrm{H}$ and $\mathrm{C}-\mathrm{H}$, indicating the presence of alkenes/aromatic hydrocarbons and alkanes, respectively [65-67]. The sharp band around 1220 is due to $\mathrm{C}-\mathrm{O}$ vibrations indicating the presence of alcohols and esters. The fingerprint region bands between 900 and $620 \mathrm{~cm}^{-1}$ are ascribed to aromatic $\mathrm{C}-\mathrm{H}$ bending vibrations while the ones at around $550 \mathrm{~cm}^{-1}$ are due to alkyl halides [63-68]. Similar spectral characteristics were observed with bio-oil produced with HZSM-5 and ZEOA (Figure 6b) with respect to the oil from the non-catalytic process. However, comparing the spectra of oils from HZSM-5 and ZEOA with ZSM-5, improvements in the peaks around 1462 and $1384 \mathrm{~cm}^{-1}$, and the fingerprint region between 900 and $620 \mathrm{~cm}^{-1}$ were also noted, which implies more alkenes in the oil. This may be connected to the improved pore characteristics of the respective catalysts which promote the deoxygenation of large oxygen-containing organic molecules to smaller hydrocarbons [45].
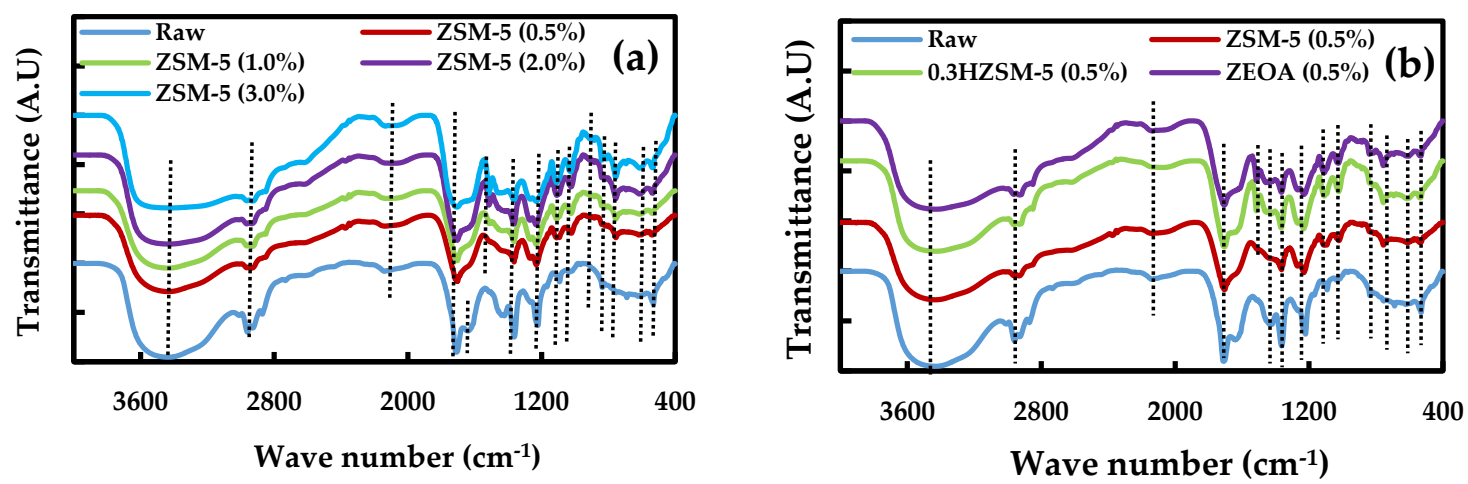

Figure 6. Averaged FTIR spectra (a) auto-smoothed and (b) auto-baseline corrected) of bio-oil samples.

\subsection{GC-MS Analysis of the Organic Phase Bio-Oil}

Identification of chemical compounds in the bio-oil samples was carried out by GC-MS. A library search using the MS NIST Library 2011 revealed that the oil was made up of various hydrocarbons, aromatics, phenols, furans, acids, ketones and alcohols. These organic compounds were further categorized into hydrocarbons, aromatics, phenolics, alcohols and other oxygenates (Figure 7) in order to evaluate the effect of ZSM-5 catalyst loading on the distribution of chemical compounds in the oil. The hydrocarbons consist of alkanes, alkenes and alkynes which account for $23.2 \%$ in the oil from the non-catalytic process while $29.52 \%, 23.20 \%, 28.89 \%$ and $26.95 \%$ was recorded in the oil produced with $0.5,1.0,2.0$ and $3.0 \mathrm{wt} \%$ catalyst loading, respectively. The proportion of olefins in the total hydrocarbons in the oil from catalytic process $(12.4 \%-29.53 \%)$ was higher than that obtained from the non-catalytic process (1.55\%). This observation can be attributed to the acidity of the ZSM- 5 catalyst which is known for the selective production of olefins through cracking of oxygenated compounds at higher temperatures similar to the temperature $\left(600^{\circ} \mathrm{C}\right)$ used in this study $[29,69,70]$. The aromatic hydrocarbons were detected only in the oil from the catalytic process which consist 
of 4a-Methyl-1,2,4a,5,8,8a-hexahydro-naphthalene, 1,1'-ethylidenebisbenzene, and bis (methylthio) methylbenzene. These compounds are produced via a series of complex chemical reactions such as cracking, oligomerization, dehydrogenation, and aromatization promoted by the Brønsted acid cites of the ZSM-5. With increasing catalyst loading, the total aromatic yield increased. $12.18 \%$ and $15.19 \%$ naphthalene was recorded with 0.5 and $1.0 \mathrm{wt} \%$ ZSM- 5 loading, respectively, which is mainly the product of condensed fragments from the surface active cites of the ZSM-5 while $15.69 \%$ and $18.88 \%$ of benzene was observed with 2.0 and $3.0 \mathrm{wt} \%$ catalyst loading. Similar observations have been reported in the literature $[23,31,71]$. The phenolics, mainly phenols and other oxygenates observed in the bio-oil decreased with catalyst loading as a result of dehydration, decarbonylation and decarboxylation which transformed them to smaller molecular units such as benzene [23,31,71]. Comparing the product distribution of ZSM- 5 with $0.3 \mathrm{HZSM}-5$ and ZEOA, the hydrocarbon yield from $0.3 \mathrm{HZSM}-5$ and ZEOA was $23.51 \%$ and $30.69 \%$ (Figure $7 b$ ), respectively, compared to ZSM-5 which had $29.52 \%$.
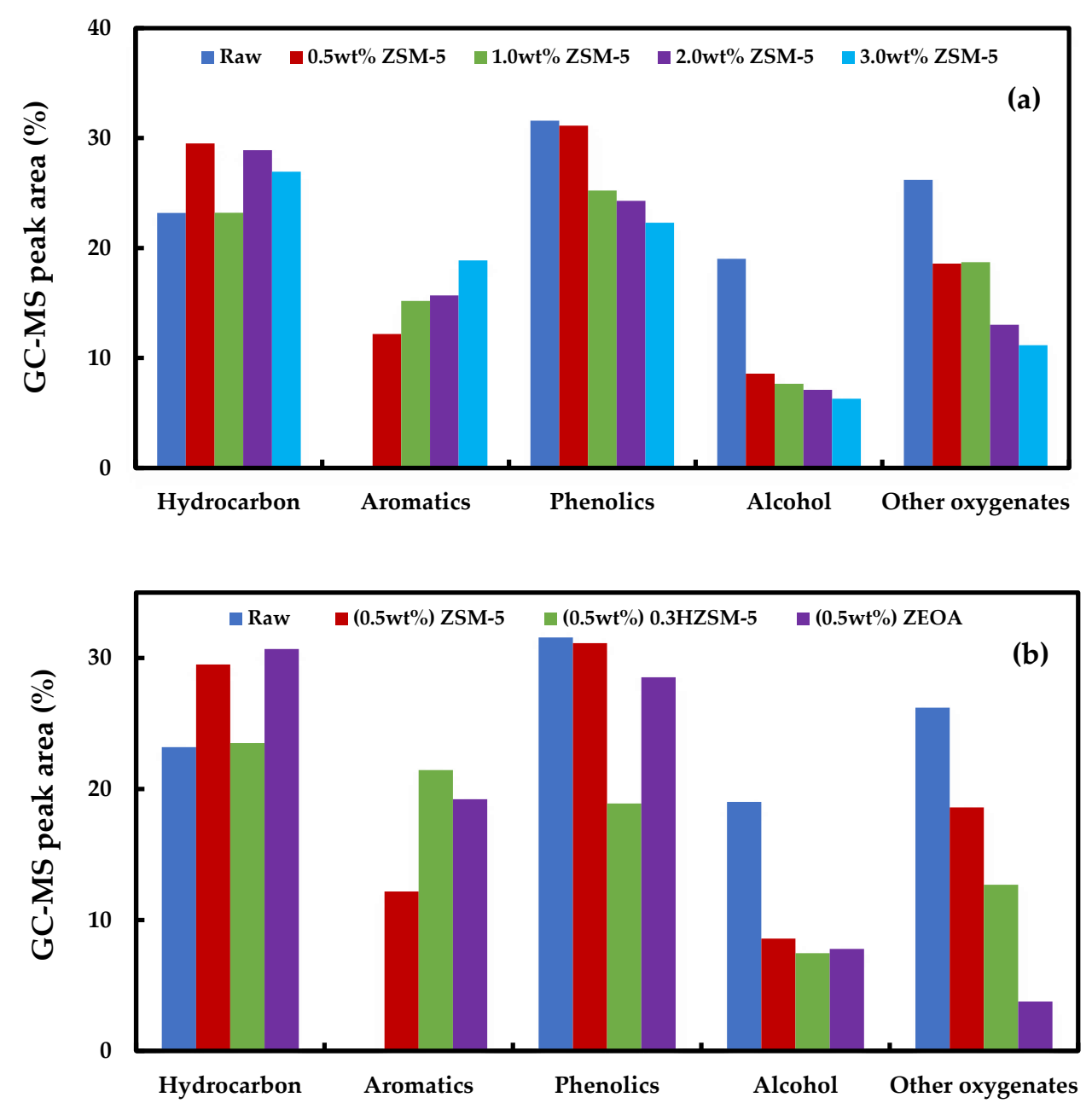

Figure 7. Groups of organic compounds detected in the bio-oil samples using GC-MS (a) ZSM-5 loading (0.5-3.0 wt \%); (b) $0.5 \mathrm{wt} \%$ loading of ZSM-5, 0.3HZSM-5 and ZEOA.

The aromatic production was $21.45 \%$ and $19.22 \%$ with 0.3 HZSM- 5 and ZEOA while that recorded with ZSM-5 was $12.18 \%$. Phenolics recorded with ZSM-5 were $31.14 \%$, but decreased to $28.53 \%$ and $18.89 \%$ with ZEOA and 0.3HZSM-5. Also, other oxygenates decreased with ZEOA $(3.77 \%)$ and $0.3 \mathrm{HZSM}-5(12.69 \%)$ while $18.59 \%$ oxygenate was observed with ZSM-5. The increase in the aromatics, hydrocarbons and reduction in the phenolics and other oxygenates in the oil produced with ZEOA and 0.3HZSM-5 can be linked to the mesoporousity of the respective catalyst which 
perhaps reduces the steric hindrance of large organic molecules associated with the microstructure of ZSM-5 [45,69,72]. Furthermore, the composition of aromatics from 0.3HZSM-5 and ZEOA was mainly benzene, compared to the aromatics from ZSM- 5 which mainly consisted of naphthalene (PAH). The increase in the benzene content and reduction of phenols could also be attributed to the differences in the amount of acid sites. Similar observations have been reported in the literature $[45,72]$.

\subsection{GC Analysis of the Non-Condensable Gas}

The composition of the non-condensable gas analyzed by GC is summarized in Table 3. High levels of methane in the non-condensable gas from the non-catalytic pyrolysis implies thermal cracking mechanisms that produce small organic molecules during the pyrolysis. The proportion of methane in the gas decreased in the catalytic pyrolysis. With increasing ZSM-5 loading, a significant drop in the methane yield was observed, which suggests that the catalysts promoted the conversion of methane precursors to form aromatic hydrocarbons [73]. Higher composition of $\mathrm{CO}$ and $\mathrm{CO}_{2}$ in the non-condensables from the catalytic process was recorded, compared to the non-catalytic pyrolysis which is an indication of decarbonylation and decarboxylation [27,49,66-74].

Table 3. Composition of non-condensable gases.

\begin{tabular}{cccccc}
\hline \multirow{2}{*}{ Catalyst Type } & \multirow{2}{*}{ Catalyst Loading (wt \%) } & \multicolumn{4}{c}{ Gas Composition (vol \%) $\mathbf{~ N}_{\mathbf{2}}$-Free Basis } \\
\cline { 3 - 6 } & & $\mathbf{C H}_{\mathbf{4}}$ & $\mathbf{H}_{\mathbf{2}}$ & $\mathbf{C O}$ & $\mathbf{C O}_{\mathbf{2}}$ \\
\hline Raw & 0.00 & 2.72 & 0.56 & 14.04 & 25.32 \\
ZSM-5 & 0.50 & 2.40 & 0.32 & 20.87 & 29.94 \\
ZSM-5 & 1.00 & 2.26 & 0.31 & 22.97 & 33.32 \\
ZSM-5 & 2.00 & 2.01 & 0.34 & 24.67 & 36.07 \\
ZSM-5 & 3.00 & 1.94 & 0.36 & 26.14 & 37.95 \\
ZEOA & 0.50 & 2.19 & 0.33 & 26.16 & 31.65 \\
0.3 HZSM-5 & 0.50 & 2.32 & 0.29 & 29.23 & 31.80 \\
\hline
\end{tabular}

\section{Conclusions}

This study gives a background on the catalytic pyrolysis of Napier grass. It dwells on the operating parameters that affect the product distribution and the quality of the resulting bio-oil and discusses experimental results using three zeolite-based catalysts: ZSM-5, 0.3HZSM-5 and zinc exchanged Zeolite A. The results summary can be summarized as follows:

- ZSM-5 catalyst loading between 0.5 and $1.0 \mathrm{wt} \%$ had no significant impact on the oil yield compared to higher catalyst loadings at 2.0 and $3.0 \mathrm{wt} \%$. The yield of non-condensable gas increased with catalyst loading. Impact of ZSM- 5 on the yield of bio-char was minimal.

- Organic compounds in the bio-oil produced with ZSM-5 were made up of mainly hydrocarbons, aromatics and phenols. Catalyst loadings between 0.5 and $1.0 \mathrm{wt} \%$ promoted the yield of polyaromatic hydrocarbon (naphthalene) while benzene dominated the aromatics when 2.0 and $3.0 \mathrm{wt} \%$ catalyst loading were employed.

- Desilication of ZSM-5 with NaOH produced a mesoporous 0.3HZSM-5. Bio-oil yield decreased with HZSM- 5 and increased with ZEOA compared to ZSM- 5 at $0.5 \mathrm{wt} \%$ loading. The organic phase composition of the bio-oil from 0.3HZSM- 5 and ZEOA were lower than that from of ZSM-5. Higher hydrocarbon yield was recorded, particularly with ZEOA, and the aromatics were mainly benzenes. Reduction in the phenolic content and other oxygenated compounds were also recorded. This observation was attributed to the improved pore structure and the acid sites of the catalysts. Higher composition of $\mathrm{CO}$ and $\mathrm{CO}_{2}$ was observed in the non-condensable gas from the catalytic pyrolysis compared to the non-catalytic pyrolysis and was attributed to decarbonylation and decarboxylation reactions.

- This study has demonstrated that bio-oil with high fuel quality and other value added chemicals can be produced from pyrolysis of Napier grass over acidic zeolite-based catalysts. 
Acknowledgments: This project was supported by the Crops for the Future (CFF) and the University of Nottingham under the grant BioP1-005.

Author Contributions: Isah Yakub Mohammed, Yousif Abdalla Abakr, Feroz Kabir Kazi and Suzana Yusup conceived and designed the experiments; Yahaya Muhammad Sani and Peter Adeniyi Alaba synthesized and characterized the catalysts; Isah Yakub Mohammed and Yousif Abdalla Abakr produced and characterized the bio-oil; Yahaya Muhammad Sani and Peter Adeniyi Alaba analyzed the gas composition; Feroz Kabir Kazi and Suzana Susup analyzed the data; Isah Yakub Mohammed, Yousif Abdalla Abakr, Feroz Kabir Kazi and Suzana Yusup wrote the manuscript.

Conflicts of Interest: The authors declare no conflict of interest.

\section{References}

1. Yakub, M.I.; Mohamed, S.; Danladi, S.U. Technical and Economic Considerations of Post-combustion Carbon Capture in a Coal Fired Power Plant. Int. J. Adv. Eng. Technol. 2014, 7, 1549-1581.

2. Mohammed, I.Y. Optimization and Sensitivity Analysis of Post-combustion Carbon Capture Using DEA Solvent in a Coal Fired Power Plant. Int. J. Adv. Eng. Technol. 2015, 7, 1681-1690.

3. Mohammed, I.Y.; Samah, M.; Mohamed, A.; Sabina, G. Comparison of Selexol ${ }^{\mathrm{TM}}$ and Rectisol ${ }^{\circledR}$ Technologies $^{-}$ in an Integrated Gasification Combined Cycle (IGCC) Plant for Clean Energy Production. Int. J. Eng. Res. 2014, 3, 742-744. [CrossRef]

4. Yakub, M.I.; Abdalla, A.Y.; Feroz, K.K.; Suzana, Y.; Ibraheem, A.; Chin, S.A. Pyrolysis of Oil Palm Residues in a Fixed Bed Tubular Reactor. J. Power Energy Eng. 2015, 3, 185-193. [CrossRef]

5. Gebreslassie, B.H.; Slivinsky, M.; Wang, B.; You, F. Life cycle optimization for sustainable design and operations of hydrocarbon biorefinery via fast pyrolysis, hydrotreating and hydrocracking. Comput. Chem. Eng. 2013, 50, 71-91. [CrossRef]

6. Liew, W.H.; Hassim, M.H.; Ng, D.S.K. Review of evolution, technology and sustainability assessments of biofuel production. J. Clean. Prod. 2014, 71, 11-29. [CrossRef]

7. Park, S.R.; Pandey, A.K.; Tyagi, V.V.; Tyagi, S.K. Energy and exergy analysis of typical renewable energy systems. Renew. Sustain. Energy Rev. 2014, 30, 105-123. [CrossRef]

8. Ming, Z.; Ximei, L.; Yulong, L.; Lilin, P. Review of renewable energy investment and financing in China: Status, mode, issues and countermeasures. Renew. Sustain. Energy Rev. 2014, 31, 23-37. [CrossRef]

9. Nigam, P.S.; Singh, A. Production of liquid biofuels from renewable resources. Prog. Energy Combust. Sci. 2011, 37, 52-68. [CrossRef]

10. Srirangan, K.; Akawi, L.; Moo-Young, M.; Chou, C.P. Towards sustainable production of clean energy carriers from biomass resources. Appl. Energy 2012, 100, 172-186. [CrossRef]

11. Samson, R.; Mani, S.; Boddey, R.; Sokhansanj, S.; Quesada, D.; Urquiaga, S.; Reis, V.; Ho Lem, C. The Potential of C4 Perennial Grasses for Developing a Global BIOHEAT Industry. Crit. Rev. Plant Sci. 2005, 24, 461-495. [CrossRef]

12. Mohammed, I.Y.; Abakr, Y.A.; Kazi, F.K.; Yusup, S.; Alshareef, I.; Chin, S.A. Comprehensive Characterization of Napier Grass as a Feedstock for Thermochemical Conversion. Energies 2015, 8, 3403-3417. [CrossRef]

13. Mohammed, I.Y.; Abakr, Y.A.; Kazi, F.K.; Yusup, S.; Alshareef, I.; Chin, S.A. Pyrolysis of Napier Grass in a Fixed Bed Reactor: Effect of Operating Conditions on Product Yields and Characteristics. BioResources 2015, 10, 6457-6478. [CrossRef]

14. Bridgwater, A.V. Review of Fast Pyrolysis of biomass and product upgrading. Biomass Bioenergy 2012, 38, 68-94. [CrossRef]

15. Kebelmann, K.; Hornung, A.; Karsten, U.; Griffiths, G. Intermediate pyrolysis and product identification by TGA and Py-GC/MS of green microalgae and their extracted protein and lipid components. Biomass Bioenergy 2013, 49, 38-48. [CrossRef]

16. Mahmood, A.S.N.; Brammer, J.G.; Hornung, A.; Steele, A.; Poulston, S. The inter-mediate pyrolysis and catalytic steam reforming of Brewers spent grain. J. Anal. Appl. Pyrolysis 2013, 103, 328-342. [CrossRef]

17. Tripathi, M.; Sahu, J.N.; Ganesan, P. Effect of process parameters on production of biochar from biomass waste through pyrolysis: A review. Renew. Sustain. Energy Rev. 2016, 55, 467-481. [CrossRef]

18. Iliopoulou, E.F.; Stefanidis, S.D.; Kalogiannis, K.G.; Delimitis, A.; Lappas1, A.A.; Triantafyllidis, K.S. Catalytic upgrading of biomass pyrolysis vapors using transition metal-modified ZSM-5 zeolite. Appl. Catal. B Environ. 2010, 127, 281-290. [CrossRef] 
19. Carlson, T.R.; Cheng, Y.; Jae, J.; Huber, G.W. Production of green aromatics and olefins by catalytic fast pyrolysis of wood sawdust. Energy Environ. Sci. 2011, 4, 145-161. [CrossRef]

20. Compton, D.L.; Jackson, M.A.; Mihalcik, D.J.; Mullen, C.A.; Boateng, A.A. Catalytic pyrolysis of oak via pyroprobe and bench scale, packed bed pyrolysis reactors. J. Anal. Appl. Pyrolysis 2011, 90, 174-181. [CrossRef]

21. Du, S.; Sun, Y.; Gamliel, D.P.; Valla, J.A.; Bollas, G.M. Catalytic pyrolysis of miscanthus $\times$ giganteus in a spouted bed reactor. Bioresour. Technol. 2014, 169, 188-197. [CrossRef] [PubMed]

22. Choi, Y.S.; Lee, K.-H.; Zhang, J.; Brown, R.C.; Shanks, B.H. Manipulation of chemical species in bio-oil using in situ catalytic fast pyrolysis in both a bench-scale fluidized bed pyrolyzer and micropyrolyzer. Biomass Bioenergy 2015, 81, 256-264. [CrossRef]

23. Park, Y.-K.; Yoo, M.L.; Jin, S.H.; Park, S.H. Catalytic fast pyrolysis of waste pepper stems over HZSM-5. Renew. Energy 2015, 79, 20-27. [CrossRef]

24. Jae, J.; Tompsett, G.A.; Foster, A.J.; Hammond, K.D.; Auerbach, S.M.; Lobo, R.F.; Huber, G.W. Investigation into the shape selectivity of zeolite catalysts for biomass conversion. J. Catal. 2011, 279, 257-268. [CrossRef]

25. Zhang, B.; Zhong, Z.-P.; Wang, X.-B.; Ding, K.; Song, Z.-W. Catalytic upgrading of fast pyrolysis biomass vapors over fresh, spent and regenerated ZSM-5 zeolites. Fuel Process. Technol. 2015, 138, 430-434. [CrossRef]

26. Carlson, T.R.; Vispute, T.P.; Huber, G.W. Green gasoline by catalytic fast pyrolysis of solid biomass derived compounds. ChemSusChem 2008, 1, 397-400. [CrossRef] [PubMed]

27. Gamliel, D.P.; Du, S.; Bollas, G.M.; Valla, J.A. Investigation of in situ and ex situ catalytic pyrolysis of miscanthus-giganteus using a PyGC-MS microsystem and comparison with a bench-scale spouted-bed reactor. Bioresour. Technol. 2015, 191, 187-196. [CrossRef] [PubMed]

28. Yildiz, G.; Ronsse, F.; Venderbosch, R.; Van Duren, R.; Kersten, S.R.A.; Prins, W. Effect of biomass ash in catalytic fast pyrolysis of pine wood. Appl. Catal. B Environ. 2015, 168-169, 203-211. [CrossRef]

29. Liu, G.; Wright, M.M.; Zhao, Q.; Brown, R.C. Catalytic fast pyrolysis of duckweed: Effects of pyrolysis parameters and optimization of aromatic production. J. Anal. Appl. Pyrolysis 2015, 112, 29-36. [CrossRef]

30. Kim, B.-S.; Kim, Y.-M.; Jae, J.; Watanabe, C.; Kim, S.; Jung, S.-C.; Kim, S.C.; Park, Y.-K. Pyrolysis and catalytic upgrading of Citrus unshiu peel. Bioresour. Technol. 2015, 194, 312-319. [CrossRef] [PubMed]

31. Ojha, D.K.; Vinu, R. Resource recovery via catalytic fast pyrolysis of polystyrene using zeolites. J. Anal. Appl. Pyrolysis 2015, 113, 349-359. [CrossRef]

32. Standard Test Method for Water Using Volumetric Karl Fischer Titration; ASTM International: West Conshohocken, PA, USA, 2001.

33. Mohammed, I.Y.; Kazi, F.K.; Abakr, Y.A.; Yusuf, S.; Razzaque, M.A. Novel Method for the Determination of Water Content and Higher Heating Value of Pyrolysis Oil. BioResources 2015, 10, 2681-2690. [CrossRef]

34. Standard Test Method for Heat of Combustion of Liquid Hydrocarbon Fuels by Bomb Calorimeter; ASTM International: West Conshohocken, PA, USA, 2009.

35. Alaba, P.A.; Sani, Y.M.; Mohammed, I.Y.; Abakr, Y.A.; Daud, W.M.A.W. Synthesis and application of hierarchical mesoporous HZSM-5 for biodiesel production from shea butter. J. Taiwan Inst. Chem. Eng. 2016, 59, 405-412. [CrossRef]

36. Shirazi, L.; Jamshidi, E.; Ghasemi, M.R. Effect of Si / Al ratio of ZSM-5 zeolite on its morphology, acidity and crystal size. Cryst. Res. Technol. 2008, 43, 1300-1306. [CrossRef]

37. Gong, F.; Yang, Z.; Hong, C.; Huang, W.; Ning, S.; Zhang, Z.; Xu, Y.; Li, Q. Selective conversion of bio-oil to light olefins: Controlling catalytic cracking for maximum olefins. Bioresour. Technol. 2011, 102, 9247-9254. [CrossRef] [PubMed]

38. Suyitno; Purbaningrum, P.S.; Danardono, D.; Salem, A.E.; Mansur, F.A. Synthesis of zeolite Socony mobil from blue silica gel and rice husk ash as catalysts for hydrothermal liquefaction. J. Eng. Sci. Technol. 2015, 10, 982-993.

39. Shaikh, I.R.; Shaikh, R.A.; Shaikh, A.A.; War, J.A.; Hangirgekar, S.P.; Shaikh, A.L.; Shaikh, P.R.; Shaikh, R.R. H-ZSM-5 Zeolite Synthesis by Sourcing Silica from the Wheat Husk Ash: Characterization and Application as a Versatile Heterogeneous Catalyst in Organic Transformations including Some Multicomponent Reactions. J. Catal. 2015, 2015, 805714. [CrossRef]

40. Huang, Y.; Wei, L.; Julson, J.; Gao, Y.; Zhao, X. Converting pine sawdust to advanced biofuel over HZSM-5 using a two-stage catalytic pyrolysis reactor. J. Anal. Appl. Pyrolysis 2015, 111, 148-155. [CrossRef] 
41. Wang, Y.; Fan, S.; Zhang, J.; Zhao, T.-S. Effect of Synthesis Conditions on the yields and properties of HZSM-5. Cryst. Res. Technol. 2015, 50, 522-527. [CrossRef]

42. Ayele, L.; Perez-Pariente, J.; Chebude, Y.; Díaz, I. Synthesis of zeolite A from Ethiopian kaolin. Microporous Mesoporous Mater. 2015, 215, 29-36. [CrossRef]

43. Bieseki, L.; Penha, F.G.; Perghera, S.B.C. Zeolite A Synthesis Employing a Brazilian Coal Ash as the Silicon and Aluminum Sourceand its Applications in Adsorption and Pigment Formulation. Mater. Res. 2013, 16, 38-43. [CrossRef]

44. Dyballa, M.; Obenaus, U.; Lang, S.; Gehring, B.; Traa, Y.; Koller, H.; Hunger, M. Brønsted sites and structural stabilization effect of acidic low-silica zeolite A prepared by partial ammonium exchange. Microporous Mesoporous Mater. 2015, 212, 110-116. [CrossRef]

45. Sing, K.S.W.; Everett, D.H.; Haul, R.A.W.; Moscou, L.; Poerotto, R.A.; Rouquerol, J.; Siemieniewska, T. Reporting physisorption data for gas/solid system with special reference to the determination of surface area and porosity. Pure Appl. Chem. 1985, 57, 603-619. [CrossRef]

46. Li, J.; Li, X.; Zhou, G.; Wang, W.; Wang, C.; Komarneni, S.; Wang, Y. Catalytic fast pyrolysis of biomass with mesoporous ZSM-5 zeolites prepared by desilication with NaOH solutions. Appl. Catal. A Gen. 2014, 470, 115-122. [CrossRef]

47. You, S.J.; Park, E.D. Effects of dealumination and desilication of H-ZSM-5 on xylose dehydration. Microporous Mesoporous Mater. 2014, 186, 121-129. [CrossRef]

48. Wang, L.; Lei, H.; Ren, S.; Bu, Q.; Liang, J.; Wei, Y.; Liu, Y.; Lee, G.-S.J.; Chen, S.; Tang, J.; et al. Aromatics and phenols from catalytic pyrolysis of Douglas fir pellets in microwave with ZSM-5 as a catalyst. J. Anal. Appl. Pyrolysis 2012, 98, 194-200. [CrossRef]

49. Jae, J.; Coolman, R.; Mountziaris, T.J.; Huber, G.W. Catalytic fast pyrolysis of lignocellulosic biomass in a process development unit with continual catalyst addition and removal. Chem. Eng. Sci. 2014, 108, 33-46. [CrossRef]

50. Naqvi, S.R.; Uemura, Y.; Yusup, S.B. Catalytic pyrolysis of paddy husk in a drop type pyrolyzer for bio-oil production: The role of temperature and catalyst. J. Anal. Appl. Pyrolysis 2014, 106, 57-62. [CrossRef]

51. Park, H.J.; Park, K.-H.; Jeon, J.-K.; Kim, J.; Ryoo, R.; Jeong, K.-E.; Park, S.H.; Park, Y.-K. Production of phenolics and aromatics by pyrolysis of Miscanthus. Fuel 2012, 97, 379-384. [CrossRef]

52. Elordi, G.; Olazar, M.; Lopez, G.; Castaño, P.; Bilbao, J. Role of pore structure in the deactivation of zeolites (HZSM-5, $\mathrm{Hb}$ and $\mathrm{HY}$ ) by coke in the pyrolysis of polyethylene in a conical spouted bed reactor. Appl. Catal. B Environ. 2011, 102, 224-231. [CrossRef]

53. Lappas, A.A.; Samolada, M.C.; Iatridis, D.K.; Voutetakis, S.S.; Vasalos, I.A. Biomass pyrolysis in a circulating fluid bed reactor for the production of fuels and chemicals. Fuel 2002, 81, 2087-2095. [CrossRef]

54. Veses, A.; Puértolas, B.; López, M.J.; Callén, M.S.; Solsona, B.; García, T. Promoting Deoxygenation of Bio-Oil by Metal-Loaded Hierarchical ZSM-5 Zeolites. ACS Sustain. Chem. Eng. 2016, 4, 1653-1660. [CrossRef]

55. Nilsen, M.H.; Antonakou, E.; Bouzga, A.; Lappas, A.; Mathisen, K.; Stöcker, M. Investigation of the effect of metal sites in Me-Al-MCM-41 ( $\mathrm{Me}=\mathrm{Fe}, \mathrm{Cu}$ or $\mathrm{Zn}$ ) on the catalytic behavior during the pyrolysis of wooden based biomass. Microporous Mesoporous Mater. 2007, 105, 189-203. [CrossRef]

56. Kelkar, S.; Saffron, C.M.; Andreassi, K.; Li, Z.; Murkute, A.; Miller, D.J.; Pinnavaia, T.J.; Kriegel, R.M. A survey of catalysts for aromatics from fast pyrolysis of biomass. Appl. Catal. B Environ. 2015, 174-175, 85-95. [CrossRef]

57. Imam, T.; Capareda, S. Characterization of bio-oil, syn-gas and bio-char from switchgrass pyrolysis at various temperatures. J. Anal. Appl. Pyrolysis 2012, 93, 170-177. [CrossRef]

58. Abu Bakar, M.S.; Titiloye, J.O. Catalytic pyrolysis of rice husk for bio-oil production. J. Anal. Appl. Pyrolysis 2013, 103, 362-368. [CrossRef]

59. Fan, Y.; Cai, Y.; Li, X.; Yin, H.; Yu, N.; Zhang, R.; Zhao, W. Rape straw as a source of bio-oil via vacuum pyrolysis: Optimization of bio-oil yield using orthogonal design method and characterization of bio-oil. J. Anal. Appl. Pyrolysis 2014, 106, 63-70. [CrossRef]

60. De Miguel Mercader, F.; Groeneveld, M.J.; Kersten, S.R.A.; Venderbosch, R.H.; Hogendoorn, J.A. Pyrolysis oil upgrading by high pressure thermal treatment. Fuel 2010, 89, 2829-2837. [CrossRef] 
61. Li, X.; Gunawan, R.; Wang, Y.; Chaiwat, W.; Hu, X.; Gholizadeh, M.; Mourant, D.; Bromly, J.; Li, C.-Z. Upgrading of bio-oil into advanced biofuels and chemicals. Part III. Changes in aromatic structure and coke forming propensity during the catalytic hydrotreatment of a fast pyrolysis bio-oil with $\mathrm{Pd} / \mathrm{C}$ catalyst. Fuel 2014, 116, 642-649. [CrossRef]

62. Garcia-Perez, M.; Chaala, A.; Pakdel, H.; Kretschmer, D.; Roy, C. Characterization of bio-oils in chemical families. Biomass Bioenergy 2007, 31, 222-242. [CrossRef]

63. Nguyen, M.T.; Sengupta, D.; Raspoet, G.; Vanquickenborne, L.G. Theoretical Study of the Thermal Decomposition of Acetic Acid: Decarboxylation Versus Dehydration. J. Phys. Chem. 1995, 99, 11883-11888. [CrossRef]

64. Guo, Y.; Song, W.; Lu, J.; Ma, Q.; Xu, D.; Wang, S. Hydrothermal liquefaction of Cyanophyta: Evaluation of potential bio-crude oil production and component analysis. Algal Res. 2015, 11, 242-247. [CrossRef]

65. Bordoloi, N.; Narzari, R.; Chutia, R.S.; Bhaskar, T.; Kataki, R. Pyrolysis of Mesua ferrea and Pongamia glabra seed cover: Characterization of bio-oil and its sub-fractions. Bioresour. Technol. 2015, 178, 83-89. [CrossRef] [PubMed]

66. Lazdovica, K.; Liepina, L.; Kampars, V. Comparative wheat straw catalytic pyrolysis in the presence of zeolites, Pt/C, and Pd/C by using TGA-FTIR method. Fuel Process. Technol. 2015, 138, 645-653. [CrossRef]

67. Yorgun, S.; Yildiz, D. Slow pyrolysis of paulownia wood: Effects of pyrolysis parameters on product yields and bio-oil characterization. J. Anal. Appl. Pyrolysis 2015, 114, 68-78. [CrossRef]

68. Ben, H.; Ragauskas, A.J. Torrefaction of Loblolly Pine. Green Chem. 2012, 14, 72-76. [CrossRef]

69. Gudka, B.; Jones, J.M.; Lea-Langton, A.R.; Williams, A.; Saddawi, A. A review of the mitigation of deposition and emission problems during biomass combustion through washing pre-treatment. J. Energy Inst. 2015. in press. [CrossRef]

70. Zhang, H.; Xiao, R.; Jin, B.; Xiao, G.; Chen, R. Biomass catalytic pyrolysis to produce olefins and aromatics with a physically mixed catalyst. Bioresour. Technol. 2013, 140, 256-262. [CrossRef] [PubMed]

71. Rezaei, P.S.; Shafaghat, H.; Daud, W.M.A.W. Production of green aromatics and olefins by catalytic cracking of oxygenate compounds derived from biomass pyrolysis: A review. Appl. Catal. A Gen. 2014, 469, 490-511. [CrossRef]

72. Alaba, P.A.; Sani, Y.M.; Mohammed, I.Y.; Daud, W.M.A.W. Insight into catalyst deactivation mechanism and suppression techniques in thermocatalytic deoxygenation of bio-oil over zeolites. Rev. Chem. Eng. 2015, 32, 71-91. [CrossRef]

73. Puertolas, B.; Veses, A.; Callen, M.S.; Mitchell, S.; Garcia, T.; Perez-Ramirez, J. Porosity-Acidity Interplay in Hierarchical ZSM-5 Zeolites for Pyrolysis Oil Valorization to Aromatics. Chem. Sus. Chem. 2015, 8, 3283-3293. [CrossRef] [PubMed]

74. Fischer, A.; Du, S.; Valla, J.A.; Bollas, G.M. The eff ect of temperature, heating rate, and ZSM- 5 catalyst on the product selectivity of the fast pyrolysis of spent coffee grounds. RSC Adv. 2015, 5, 29252-29261. [CrossRef]

(C) 2016 by the authors; licensee MDPI, Basel, Switzerland. This article is an open access article distributed under the terms and conditions of the Creative Commons by Attribution (CC-BY) license (http://creativecommons.org/licenses/by/4.0/). 